\title{
Engineering Students Attitude towards On-Line Shopping in Dindigul
}

\author{
Mathankumar. G, Kavitha Shanmugam
}

\begin{abstract}
The demonstration of buying items or administrations over the web is approached line shopping. In this age of quick moving way of life, building understudies are busier that what they were couple of years back. Today both urban and provincial regions appreciate web offices. It is absolutely hence building understudies are additionally buying the items or administrations on the web. The reason for this examination is to dissect factors influencing on internet shopping conduct of customers that may be a standout amongst the most essential issues of web based business and advertising field. To research these speculations 150 polls scattered among online customers for example designing undergrads in Dindigul. Respondents to the survey were purchasers of on-line in Dindigul which arbitrarily chose. At long last factor investigation was utilized on information so as to test conjectures of study.
\end{abstract}

Index Terms: Attitude, on-line shopping, engineering students I. INTRODUCTION

The term Internet is as a business instrument for organizations and people. Web turned into another middle person among organizations and their building understudies. Today, the Internet is an open, agreeable and self-supporting office available to a huge number of people around the world. These days; Internet acknowledged as s critical compelling interchanges channel testing with the customary ones, for example, Radio, Magazines, and TV. The Internet shop offers divergent methods for online correspondences with correspondence contrasts instruments that need a superior choice of their impact on client interchanges. The web obvious capacities include headings for gathering data, obtaining a products, or portrayal an administration. Web innovation headway takes into account the development of internet shopping choices past conventional strategies, which might be additional time squandering. With a developing number of people turning towards the Internet and the universe of web based business to shop, undertaking, make installments, and complete web based banking, new mechanical progressions should come to fruition to make these exchanges secure. The developments of people are floating towards increasingly comprehensive utilization of the Internet as innovation comfort, data accessibility, and the capacity to cooperate through the Internet increment and create. Shopper conduct is the basic of doing every business. Also, organizations keep on building up an online nearness, they are finding that a few purchasers are as yet hesitant to switch in that equivalent course.

\section{LITERATURE REVIEW}

Zhang (2009) inborn inspiration for Internet shopping is caught by the "satisfaction" develop in our structure. Inherent esteem or "happiness" gets from the valuation for an ordeal for the good of its own, aside from whatever other outcome that may result.

Menon (2010) says that If customers make the most of their web based shopping background, they have an increasingly uplifting frame of mind toward web based shopping, and are bound to embrace the Internet as a shopping medium. In our system, we recognize three inert elements of "satisfaction" develop, including "idealism", "delight", and "excitement" "Idealism" is reflected in the happiness that originates from taking part in exercises that are retaining, to the point of offering a departure from the requests of the everyday world. "Delight" is how much an individual feels better, blissful, upbeat, or fulfilled in internet shopping.

Herna'ndez et al. (2011) in an examination "Age, sexual orientation and pay: do them truly direct web based shopping conduct?" Analyzed whether people's financial qualities - age, sex and pay - impact their web based shopping conduct. The people broke down are experienced e-customers for example people who frequently make buys on the web. The aftereffects of their exploration demonstrate that financial factors moderate neither the impact of past utilization of the web nor the frames of mind of web based business; to put it plainly, they don't condition the conduct of the accomplished e-customer.

\section{OBJECTIVES}

To analyze the behaviour towards web based shopping among male and female engineering colleges in Dindigul town.

\section{HYPOTHESIS}

$\mathrm{H}_{0}$ : There is no significant difference between the consumer behaviour towards online shopping between male and female engineering colleges students in Dindigul town.

$\mathrm{H}_{1}$ : There is a significant difference between the consumer behaviour towards online shopping between male and female engineering colleges students in Dindigul town. 


\section{V.RESEARCH METHODOLOGY}

Research Method: - Exploratory

Sampling Technique: - Convenience Sampling

Sample Unit: - Students of engineering colleges in Dindigul town

Sample Size: - 150

Tools for Data Collection: - Questionnaire

Tools for Data Analysis: - autonomous sample test

\section{RESULTS}

Table 1 devalues that $\mathrm{p}$ esteem is .890 accordingly invalidX theories $\mathrm{H} 01$ can't be rejected at $5 \%$ dimension of hugeness at ${ }_{1}$ $5 \%$ dimension of noteworthiness. In this way no noteworthy contrast was found similarly as the consumer disposition towards internet shopping among male and femalle ${ }^{2}$ engineering students is concerned.

Table 1: Group Statistics

\begin{tabular}{|l|l|l|l|l|l|}
\hline & VAR 2 & $\mathrm{N}$ & Mean & SD & S.E \\
\hline \multirow{2}{*}{$\begin{array}{l}\text { VAR } \\
1\end{array}$} & Male & 75 & 4.21 & 0.399 & 0.052 \\
\cline { 2 - 6 } & Female & 75 & 4.01 & 0.359 & 0.026 \\
\hline
\end{tabular}

\section{MULTIPLE REGRESSION ANALYSIS}

In this previous investigation, the relationship of eash factor with the frame of mind of engineering students buy 7 conduct in Dindigul has been contemplated. The investigationx has been conveyed forward into a relapse examination in this area is given in table 2 which demonstrates that there is a noteworthy connection between nine variables with frame of mind.

Table 2: Simple Correlation of Selected Factors with Attitude

\begin{tabular}{|c|l|c|c|c|}
\hline $\begin{array}{c}\text { S.N } \\
\text { o }\end{array}$ & Factors & $\begin{array}{c}\text { Correlation } \\
\text { Co-efficient }\end{array}$ & $\begin{array}{c}\text { Table } \\
\text { Value } \\
\text { "r" }\end{array}$ & Result \\
\hline 1. & Gender & 0.049 & 0.088 & $\mathrm{NS}$ \\
\hline 2. & Age & 0.108 & 0.088 & $\mathrm{~S}$ \\
\hline 3. & Education & -0.083 & 0.088 & $\mathrm{NS}$ \\
\hline 4. & $\begin{array}{l}\text { Type of } \\
\text { Family }\end{array}$ & 0.104 & 0.088 & $\mathrm{~S}$ \\
\hline 5. & $\begin{array}{l}\text { Size of } \\
\text { Family }\end{array}$ & 0.349 & 0.088 & $\mathrm{~S}$ \\
\hline 6. & $\begin{array}{l}\text { Status of } \\
\text { Employme } \\
\text { nt (Parents) }\end{array}$ & 0.215 & 0.088 & $\mathrm{~S}$ \\
\hline 7. & $\begin{array}{l}\text { Annual } \\
\text { Income }\end{array}$ & 0.149 & 0.088 & $\mathrm{NS}$ \\
\hline 8. & $\begin{array}{l}\text { Awareness } \\
\text { of Online } \\
\text { purchase }\end{array}$ & -0.1049 & 0.088 & $\mathrm{~S}$ \\
\hline
\end{tabular}

Source: Primary data

\section{INTER - CORRELATION}

The partial Regression Co-productive of the seven elements with engineering students ' demeanor is (3.40) demonstrating that the seven elements, separately contribute altogether to the varieties in student's frame of mind when the impact of different components is kept consistent. As the R2 esteem is 0.597 the level of consistency of respondents' frame of mind as far as these variables is 59.70 percent.

Table 3: Inter Correlation among Independent Variables

\begin{tabular}{|c|c|c|c|c|c|c|c|c|c|}
\hline & $\mathbf{Y}$ & $\mathbf{X}_{1}$ & $\mathbf{X}_{2}$ & $\mathbf{X}_{3}$ & $\mathbf{X}_{4}$ & $\mathbf{X}_{5}$ & $X_{6}$ & $\mathbf{X}_{7}$ & $\begin{array}{l}X \\
8\end{array}$ \\
\hline $\mathbf{Y}$ & 1 & & & & & & & & \\
\hline $\mathrm{d} \mathbf{X}$ & 0.049 & 1 & & & & & & & \\
\hline$y_{X}$ & 0.108 & -0.10 & 1 & & & & & & \\
\hline 2 & & 0 & & & & & & & \\
\hline $\mathbf{X}$ & -0.08 & -0.08 & -0.01 & 1 & & & & & \\
\hline 3 & 3 & 0 & 5 & & & & & & \\
\hline $\mathbf{X}$ & -0.07 & 0.168 & -0.37 & 0.318 & 1 & & & & \\
\hline 4 & 8 & & 2 & & & & & & \\
\hline $\mathbf{X}$ & 0.104 & -0.32 & 0.232 & -0.36 & -0.31 & 1 & & & \\
\hline 5 & & 2 & & 4 & 9 & & & & \\
\hline $\mathbf{X}$ & 0.349 & -0.04 & 0.273 & -0.36 & -0.42 & 0.409 & 1 & & \\
\hline 6 & & 0 & & 5 & 0 & & & & \\
\hline $\mathbf{X}$ & 0.137 & 0.194 & -0.33 & 0.291 & 0.654 & -0.26 & 0.26 & 1 & \\
\hline $\mathrm{y}^{7}$ & & & 0 & & & 0 & 2 & & \\
\hline & 0.149 & -0.09 & 0.039 & -0.10 & -0.14 & 0.250 & 0.37 & -0.00 & 1 \\
\hline & & 1 & & 1 & 2 & & 5 & 1 & \\
\hline
\end{tabular}

Significant at $5 \%$

Table value of correlation $=0.088$

Table 4: Multiple Regression Analysis of Nine Factors with Attitude

\begin{tabular}{|c|c|c|c|c|c|}
\hline $\begin{array}{c}\text { S.N } \\
\boldsymbol{o}\end{array}$ & Factors & $\begin{array}{c}\text { Partial } \\
\text { Regressio } \\
\boldsymbol{n}\end{array}$ & $\begin{array}{c}\text { SE of } \\
\text { Partial } \\
\text { Regressio } \\
\boldsymbol{n}\end{array}$ & $\begin{array}{c}\text { “t” } \\
\text { Value }\end{array}$ & $\begin{array}{c}\text { Significanc } \\
\boldsymbol{e}\end{array}$ \\
\hline 1. & Sex & 4.409 & 4.214 & 0.149 & $\mathrm{NS}$ \\
\hline 2. & Age & 4.971 & 2.905 & 1.334 & $\mathrm{~S}$ \\
\hline 3. & Education & -0.154 & 3.828 & -0.04 & $\mathrm{NS}$ \\
\hline 4. & $\begin{array}{c}\text { Type of } \\
\text { Family }\end{array}$ & 6.757 & 6.118 & 1.104 & $\mathrm{~S}$ \\
\hline 5. & $\begin{array}{c}\text { Size of } \\
\text { Family }\end{array}$ & 13.944 & 5.748 & 2.426 & $\mathrm{~S}$ \\
\hline 6. & $\begin{array}{c}\text { Status of } \\
\text { Employment }\end{array}$ & 4.340 & 3.888 & 1.116 & $\mathrm{~S}$ \\
\hline 7. & $\begin{array}{c}\text { Annual } \\
\text { Income }\end{array}$ & -0.530 & 3.239 & -0.16 & $\mathrm{NS}$ \\
\hline 8 & $\begin{array}{c}\text { Awareness } \\
\text { of Online } \\
\text { purchase }\end{array}$ & -6.955 & 5.688 & -1.34 & $\mathrm{~S}$ \\
\hline
\end{tabular}

$$
\mathrm{R}^{2}=0.629 \quad \mathrm{~F}=8.32 \text { significant }
$$

Percentage of Predictability $=62.90 \%$

As the Partial Regression Co-effective of five of the above variables is critical, the Partial Regression Analysis has been rehashed for the five huge components and the outcomes are given in Table 5.

Table 5: Partial 
Regression Analysis of Five factors with Attitude

\begin{tabular}{|c|c|c|c|c|c|}
\hline S. & Factors & $\begin{array}{c}\text { Partial } \\
\text { Regressio } \\
\boldsymbol{n}\end{array}$ & $\begin{array}{c}\text { SE of } \\
\text { Partial } \\
\text { Regressio } \\
\boldsymbol{n}\end{array}$ & $\begin{array}{c}\text { Value } \\
\text { ance }\end{array}$ & $\begin{array}{c}\text { Signific } \\
\text { ance }\end{array}$ \\
\hline 1. & Age & 4.514 & 3.854 & 1.171 & $\mathrm{~S}$ \\
\hline 2. & $\begin{array}{c}\text { Type of } \\
\text { Family }\end{array}$ & 6.891 & 5.846 & 1.179 & $\mathrm{~S}$ \\
\hline 3. & $\begin{array}{c}\text { Size of } \\
\text { Family }\end{array}$ & 14.202 & 5.286 & 2.687 & $\mathrm{~S}$ \\
\hline 4. & $\begin{array}{c}\text { Status of } \\
\text { Employment }\end{array}$ & 4.016 & 3.495 & 1.149 & $\mathrm{~S}$ \\
\hline 5. & $\begin{array}{c}\text { Awareness } \\
\text { of Online } \\
\text { purchase }\end{array}$ & -6.122 & 3.230 & -1.89 & $\mathrm{~S}$ \\
\hline
\end{tabular}

$\mathrm{R}^{2}=0.597$

$\mathrm{F}=10.37$

Percentage of Predictability $=59.70 \%$

The Partial Regression Co-productive of five elements with designing understudies' frame of mind demonstrates that all the five factors independently contribute essentially to the varieties in engineering students when the impact of the variables is kept steady. As the R2 esteem is 0.597 the level of consistency of responents as far as the five variables is $59.70 \%$.

As the " $F "$ esteem is critical, this Multiple Regression Analysis is noteworthy.

Table 6: Analysis of Variance for Regression

\begin{tabular}{|c|c|c|c|c|}
\hline Source & DF & SS & $\boldsymbol{M S}$ & $\boldsymbol{F}$ \\
\hline Regression & 4 & 93150.72 & $11643 . .8$ & 10.3 \\
& & & 4 & 7 \\
\hline Residual & 145 & 596189.36 & 1122.77 & \\
\hline Total & $\mathbf{1 9 9}$ & $\mathbf{6 8 9 3 4 0 . 0 8}$ & & \\
\hline
\end{tabular}

Significant 5\% level

IX. The Analysis of Variance of numerous relapse models for mentality shows the general hugeness of the model fitted. The coefficient of assurance R2value demonstrates that these factors set up together clarify the varieties of mentality to the degree of $59.70 \%$.

\section{X.CONCLUSION}

On-line shopping has turned out to be amazingly prominent in the course of the most recent decade. Used generally by the "Net-Generation", this administration is very helpful. Albeit internet shopping can be advantageous and useful there are additionally some potential issues that can emerge. Buyers have been believed to uncover diverse purchasing practices when shopping on the web than, when they are shopping in a physical retail locations. In the wake of applying measurable systems it was discovered that there is no critical distinction among the reaction of male and female engineering students in Dindigul town. This makes it vital that retailers need to ponder the customer conduct and influence changes so as to stay productive and thriving. The general outcomes demonstrate that the respondents have seen web based shopping in a positive way. This plainly legitimizes the task development of web based shopping. The outcomes can likewise be utilized by different associations to distinguish their objective client portions. India has an incredible future in internet shopping.

\section{REFERENCES}

1. Avadhani V.A., Marketing of financial services and markets, Himalaya Publishing House, Delhi, 1999.

2. Cooper, D.R. and Schindler, P.S., Business Research Methods. 7th ed Boston:McGraw-Hill/Irwin, 2001.

3. Kothari, C.R., Research Methodology, Second revised - edition, New Age international (P) Limited, Publishers, New Delhi, 1990.

4. Kotler, p., Marketing Management, Prentice-Hall, India, 2001.

5. Elhance, D.N., Fundamentals of Statistics, Kitab Mahal, New Delhi, 1984 